\title{
DOMINASI PERAN PASANGAN USIA SUBUR DALAM PENGAMBILAN KEPUTUSAN MENJADI AKSEPTOR KELUARGA BERENCANA DI WILAYAH KERJA PUSKESMAS MINASA UPA MAKASSAR
}

\section{DOMINATION OF FERTILE AGE COUPLE ROLE IN TAKING DECISION TO BE A FAMILY PLAN ACCEPTOR IN THE WORKING AREA OF PUBLIC HEALTH CENTER MINASA UPA MAKASSAR}

\author{
Hidayati, Marsuki \\ Midwifery Department of Health Politechnic Makassar \\ E-mail korespondensi : hidayatikhalik@gmail.com
}

\begin{abstract}
The problem in Indonesia is the relatively high population growth rate. Estimated mid-population (2013) of 248.8 million with a population growth rate of $1.48 \%$. One effort to reduce the population is by promoting the Family Planning (KB) program. Regarding gender, the status of women and men is also related to the decision making to choose and use contraception. The purpose of this study is to know the dominance of the Fertile Age Couple role in decision making to become a family planning acceptor in the working area of the Minasa Upa Public Health Center in Makassar with the study period from August to November 2017. This type of research is descriptive survey method that is collecting as much data as possible about the factors that are supporting quality, then analyzing these factors to look for its role, using a community survey approach. Researchers analyze the results of interviews and observations by making a common thread to generalize a complex picture of its central phenomenon. Then make an interpretation of the meaning of data through reflection, namely reflecting biases and values, personal assumptions into the research report. The results of the study found that in determining the choice of contraceptive method that is by way of deliberation to produce a joint decision and agree on the decision. That the party that determines in the selection of contraceptive methods is on the part of the wife and finally the husband will approve the decision. Matters that influence the choice of contraceptive methods show the role of the husband is less involved, because he believes that family planning is a women's problem.
\end{abstract}

Keyword : contraception, decision maker, fertile age couple

\section{ABSTRAK}

Masalah yang terdapat di Indonesia adalah laju pertumbuhan penduduk yang relatif masih tinggi. Perkiraan penduduk pertengahan (2013) sebesar 248,8 juta jiwa dengan laju pertumbuhan penduduk sebesar $1,48 \%$. Salah satu upaya menekan jumlah penduduk adalah dengan menggalakkan program Keluarga Berencana (KB). Berkaitan dengan gender, status perempuan dan laki-laki berhubungan juga dengan pengambilan keputusan untuk memilih dan menggunakan alat kontrasepsi. Tujuan dari penelitian ini adalah diketahuinya dominasi peran Pasangan Usia Subur dalam pengambilan keputusan menjadi akseptor keluarga berencana di wilayah kerja Puskesmas Minasa Upa Makassar dengan periode penelitian Agustus sampai November 2017. Jenis penelitian ini adalah deskriptif dengan metode survei yaitu mengumpulkan data sebanyak-banyaknya mengenai faktor-faktor yang merupakan pendukug terhadap kualitas, kemudian menganalisis faktor-faktor tersebut untuk dicari peranannya, menggunakan pendekatan community survey. Peneliti menganalisa hasil wawancara dan observasi dengan membuat benang merah untuk menggeneralisasikan gambaran kompleks tentang fenomena sentralnya. Kemudian membuat interpretasi tentang makna data melalui refleksi, yaitu merefleksikan bias dan nilai, asumsi personal ke dalam laporan penelitian. Hasil penelitian mendapatkan bahwa dalam menentukan pilihan metode kontrasepsi yaitu dengan cara musyawarah untuk menghasilkan keputusan bersama dan menyepakati keputusan tersebut. Bahwa pihak yang menentukan dalam pemilihan metode kontrasepsi adalah dipihak istri dan akhirnya suami akan menyetujui keputusan tersebut. Hal-hal yang berpengaruh dalam menentukan pilihan metode kontrasepsi terlihat peran suami kurang terlibat, karena beranggapan bahwa masalah KB adalah masalah perempuan.

Kata kunci : kontrasepsi, pengambilan keputusan, Pasangan Usia Subur

\section{PENDAHULUAN}

Indonesia merupakan sebuah negara berkembang dengan jumlah penduduk sebanyak 252.124.458 jiwa dengan luas wilayah 1.913.378,68 $\mathrm{km}$ dan kepadatan penduduk sebesar 131,76 jiwa/km (Depkes $\mathrm{RI}$, 2014). Masalah yang terdapat di Indonesia adalah laju pertumbuhan penduduk yang relatif masih tinggi. Perkiraan penduduk pertengahan (2013) sebesar 248,8 juta jiwa dengan laju pertumbuhan penduduk sebesar $1,48 \%$. Laju pertumbuhan ditentukan oleh kelahiran dan kematian dengan adanya perbaikan pelayanan kesehatan menyebabkan tingkat kematian rendah, sedangkan tingkat kelahiran tetap tinggi, hal ini penyebab utama ledakan penduduk.

Masalah yang terdapat di Indonesia adalah laju pertumbuhan penduduk yang 
relatif masih tinggi. Masalah demografi tersebut membawa pengaruh yang kurang menguntungkan bagi kesehatan diantaranya keadaan pemukiman yang kurang sehat. Selain itu juga berpengaruh pada angka kematian ibu dan bayi, juga angka kesakitan ibu dan bayi.

Menurut Karini (2002) menyatakan bahwa ternyata masalah kependudukan tidak hanya dilihat dari sisi demografis yang berfokus kepada aspek kuantitatif saja, namun juga memperhitungkan aspek hak hak asasi manusia serta menampung aspirasi perempuan dan laki-laki. Program Keluarga Berencana merupakan upaya yang paling efektif dalam mengendalikan laju pertumbuhan penduduk. Cakupan peserta KB baru dan KB aktif di Indonesia pada tahun 2014 dengan jumlah Pasangan Usia Subur (PUS) sebanyak 47.019.002 Device) sebanyak 555.241(7,15\%), Metode Operasi Wanita (MOW) sebanyak 116.384 $(1,5 \%)$, Metode Operasi Pria (MOP) sebanyak $16.062 \quad(0,2 \%) \quad$ Sedangkan peserta KB aktif sebanyak 35.202.908 meliputi IUD sebanyak 3.896.081 (11,07\%), MOW sebanyak 1.238 .749 (3,52\%), MOP sebanyak $241.642 \quad(0,69 \%$, implant sebanyak $3.680 .816 \quad(10,46 \%)$, kondom sebanyak $1.110 .341 \quad(3,15 \%)$, suntikan sebanyak 16.734.917 $(47,54 \%)$, dan pil KB sebanyak 8.300.362 (29,58\%) (Depkes RI, 2014).

Data tentang akseptor Keluarga Berencana yang diperoleh dari Puskesmas Minasa Upa Makassar periode Januari - Juli 2016 adalah sebanyak 5240 PUS, 3768 Akseptor KB aktif, meliputi akseptor kondom sebanyak 260, Akseptor Pil 1028, akseptor KB suntik 1592 , Akseptor KB implant sebanyak 385, akseptor KB IUD sebanyak 415, dan kseptor KB MOW (Metode Operasi Wanita), sebanyak 88. (Data puskesmas Minasa Upa Makassar).

Dewasa ini isu global tentang bias gender dalam Keluarga Berencana adalah adanya sub ordinat perempuan dalam pemilihan alat kontrasepsi. Adanya beberapa permasalahan gender termasuk juga pengambilan keputusan dipengaruhi oleh beberapa faktor yaitu sosial budaya, agama, ekonomi, pekerjaan dan peraturan perundang-undangan. Penelitian Setiadi (2015) menemukan bahwa faktor istri yang bekerja di luar rumah mempunyai pengaruh dalam meningkatnya determinasi sang istri dalam pembuatan keputusan. Dalam kelompok umur di atas 24 tahun, istri juga memiliki peran yang cukup kuat. Demikian juga, determinasi pengambilan keputusan masalah-masalah dalam keluarga baik oleh istri atau bersama-sama dengan berkontribusi besar akan meningkatkan kemampuan istri untuk mengambil keputusan dalam pemakaian kontrasepsi. Kenyataan memperlihatkan bahwa masih ada nilai-nilai masyarakat yang membatasi ruang gerak terutama perempuan di berbagai kehidupan. Secara statistik, pada umumya kaum perempuan mendapat posisi yang kurang menguntungkan dalam berbagai aspek kehidupan. Situasi ini merupakan hasil akumulasi dan akses dan nilai sosio kultural suatu masyarakat (Darahim dalam Titik, 2011). Dalam Penelitian yang lain menyampaikan hasil analisis menunjukkan bahwa peran serta suami merupakan faktor risiko perilaku penggunaan metode kontrasepsi (Yeni, 2017). Kenyataan memperlihatkan bahwa masih ada nilai-nilai masyarakat yang membatasi ruang gerak terutama perempuan di berbagai kehidupan Sejalan dengan Outcome document SDGs, Gol 5.1, yaitu mengakhiri segala bentuk diskriminasi terhadap semua perempuan dan anak perempuan dimana saja. Hasil penelitian Fitri (2015) menemukan ada hubungan dukungan suami, dengan pemilihan MKJP.

Tujuan umum penelitian ini adalah diketahuinya dominasi peran PUS dalam pengambilan keputusan menjadi akseptor keluarga berencana di wilayah kerja Puskesmas Minasa Upa Makassar, tujuan khusus penelitian adalah diketahuinya peran pasangan suami istri dalam pengambilan keputusan menjadi akseptor keluarga berencana di wilayah kerja Puskesmas Minasa Upa Makassar, diketahuinya peran istri dalam pengambilan keputusan menjadi akseptor keluarga berencana di wilayah kerja Puskesmas Minasa Upa Makassar, dan diketahuinya peran suami dalam pengambilan keputusan menjadi akseptor keluarga berencana di wilayah kerja Puskesmas Minasa Upa Makassar. 


\section{METODE \\ Desain}

Jenis penelitian ini adalah deskriptif dengan metode survei yaitu mengumpulkan data sebanyak-banyaknya mengenai faktorfaktor yang merupakan pendukung terhadap kualitas, kemudian menganalisis faktorfaktor tersebut untuk dicari peranannya, menggunakan pendekatan community survey.

\section{Tempat \\ Lokasi penelitian di Puskesmas Minasa Upa Makassar}

\section{Waktu}

Agustus - November 2017

\section{Populasi dan Sampel}

Populasi dalam penelitian ini adalah semua Pasangan Usia Subur (PUS) baik yang belum atau yang sudah menjadi akseptor KB di Wilayah kerja Puskesmas Minasa Upa Makassar selama perode penelitian. Menggunakan metode non probability sampling yaitu Purposive sampling. Besar sampel sebesar 20 respoden, 10 responden perempuan dan 10 responden laki-laki untuk dilakukan wawancara.

\section{Instrumen Penelitian}

Instrumen penelitian menggunakan format wawancara untuk memperoleh keterangan sesuai dengan tujuan penelitian.

\section{Teknik Pengumpulan Data}

Pengambilan data dilakukan dengan 2 cara yaitu :

a. Wawancara,

b. Observasi,

\section{HASIL}

\section{Karakteristik Sampel}

Sebagian besar responden berada pada rentang usia 20-35 tahun atau sebesar $90 \%$ Sasaran Program Keluarga Berencana adalah Pasangan Usia Subur, yaitu pasangan dengan rentang umur wanita $15-49$ tahun. Sebagian besar responden berada pada Paritas 2 - $4(60 \%)$ dan pada rentang usia $20-35$ tahun adalah rentang usia terbesar. Sebagian besar Responden memiliki tingkat Pendidikan tinggi 9 orang $(45 \%)$. Hal ini dapat dipahami, bahwa salah satu ciri dinamika masyarakat perkotaan yaitu tingkat pendidikan berada pada tingkat menengah dan tinggi.

\section{HASIL PENELITIAN}

Hasil wawancara

Analisa sesuai format wawancara

Dari hasil wawancara tentang "Siapa yang berpengaruh dalam proses pengambilan keputusan dalam menentukan pemilihan kontrasepsi“, didapatkan bahwa ada 2 (dua) pendapat yaitu :

Pertama ; dari Perempuan bahwa penentuan pemilihan ada di tangan istri dan ada persetujuan dari suami

Kedua ; dari pihak laki-laki bahwa penentuan pilihan adalah dengan cara diputuskan bersama. Walaupun ada pihak lain yang ikut dalam proses pemilihan, namun hal ini hanya untuk memberikan masukan dan saran.

\section{PEMBAHASAN}

Responden berjumlah 20 orang yang terdiri dan 10 orang perempuan dan 10 orang laki-laki. Responden perempuan adalah para istri dari keluarga yang telah memiliki anak lebih atau sama dengan satu orang, baik yang sudah maupun yang belum menjadi akseptor. Responden laki-laki adalah para suami dan keluarga yang sudah memiliki anak lebih atau sama dengan satu orang, baik yang sudah maupun yang belum pernah sama sekali menjadi akseptor.

Proses pengambilan keputusan dalam pemilihan metode kontrasepsi.

Proses pengambilan keputusan dalam menentukan metode kontrasepsi sebagian besar sudah sesuai dengan teori dimana dalam setiap pengambilan keputusan untuk kepentingan bersama sebaiknya mengutamakan musyawarah.

Siapa yang berpengaruh dalam pengambilan keputusan untuk menentukan pilihan metode kontrasepsi pada PUS.

Hasil wawancara menurut responden perempuan, menyatakan bahwa yang menentukan pilihan metode kontrasepsi adalah istri atau pihak perempuan dan nantinya suami akan menyetujui dengan keputusan tersebut. Namun pendapat responden laki-laki, bahwa yang menentukan pilihan metode kontrasepsi adalah berdua yaitu suami dan istri. Dalam proses musyawarah sebagian kecil ada pihak luar yang ikut campur dalam proses musyawarah tapi tidak memberikan paksaan atau tekanan namun memberikan masukan atau saran tentang kontrasepsi. 
Hal-hal yang berpengaruh dalam proses pengambilan keputusan untuk menentukan pilihan metode kontrasepsi.

Dapat ditarik kesimpulan bahwa hal hal yang berpengaruh dalam menentukan pilihan metode kontrasepsi terlihat bahwa peran suami masih kurang terlibat, karena beranggapan bahwa masalah KB adalah masalah perempuan. Dari hasil observasi dapat ditarik kesimpulan secara umum bahwa semua responden dalam menjawab pertanyaan, keadaan responden sadar dan tidak ada unsur paksaan.

\section{KESIMPULAN}

Karakteristik responden mengenai umur, paritas dan pendidikan mendasari dalam proses pengambilan keputusan untuk pemilihan metode kontrasepsi. Dalam menentukan pilihan metode kontrasepsi yaitu dengan cara musyawarah untuk menghasilkan keputusan bersama dan menyepakati keputusan tersebut. Pihak yang menentukan dalam pemilihan metode kontrasepsi adalah pihak istri dan akhirnya suami akan menyetujui keputusan tersebut. Hal-hal yang berpengaruh dalam menentukan pilihan metode kontrasepsi terlihat bahwa peran suami masih kurang terlibat, karena beranggapan bahwa masalah KB adalah masalah perempuan.

\section{SARAN}

Perlunya peningkatan pengetahuan tentang KB bagi suami. Dalam kegiatan penyuluhan perlu melibatkan partisipasi suami. Untuk itu, diperlukan kerjasama dengan tokoh masyarakat atau pemuka agama, agar setiap kegiatan yang biasa di hadiri oleh suami diselipkan materi tentang KB yang di bawakan oleh petugas PLKB setempat.

\section{Daftar Pustaka}

Depkes RI, 2014. Profil Kesehatan dan Kependudukan Indonesia.

Fitri (2015) Analisis Faktor Yang Berhubungan Dengan Pemilihan Metode Kontrasepsi Jangka Panjang (Mkjp) Pada Akseptor Kb Wanita Di Kecamatan Banyu biru Kabupaten Semarang, Unnes Journal of Public Health, ISSN 2252-6528
Hartanto, H.(2002). KB dan Kontrasepsi. Jakarta : Pustaka Sinar Harapan.

Karini, S. W.(2002). Pemberdayaan Perempuan dalam Mewujudkan Kesetaraan Gender. Buletin SMPFA.01.1.

Manuaba, 1. B. G. (1998). Ilmu Kebidanan, Penyakit Kandungan dan Keluarga Berencana. Jakarta : EGC.

Manuaba, I.B.G. (1998). Memahami Kesehatan Reproduksi Wanita. Jakarta :EGC.

Saifuddin, A.B. (2002). Buku Acuan Nasional Pelayanan Kesehatan Maternal dan Neonatal. Jakarta : YBPSP.

Setiadi dan Lilik, 2015, Pengambilan Keputusan Penggunaan Alat Kontrasepsi Istri Dalam Keluarga, Populasi, Volume 23 Nomor 1, 2015.

Syamsi, I. (2000). Pengambilan keputusan Dan Sistem informasi. Jakarata Bumi Aksara.

Titik Kurniawati, 2011, Studi Kualitatif Tentang Pengambilan Keputusan Dalam Pemilihan Metode Kontrasepsi Pada Pus Di Kota Semarang, Dinamika Kebidanan vol.1/ no.1/ januari 2011.

Wahab, A.A. (1997). Pendidikan pancasila 2. Jakarta : Departemen pendidikan dan Kebudayaan

Yeni, dkk, 2017, Paritas Dan Peran Serta Suami Dalam Pengambilan Keputusan Terhadap Penggunaan Metode Kontrasepsi. JURNAL MKMI, Vol. 13 No. 4, Desember 2017 